\title{
Dejavniki razlik v velikosti fiskalnega in nefiskalnega dela javnega sektorja med državami
}

UDK: 336.1/.5:336.2.029

\author{
Primož Pevcin \\ Univerza v Ljubljani, Fakulteta za upravo \\ primoz.pevcin@fu.uni-lj.si
}

\begin{abstract}
IZVLEČEK
Namen prispevka je s pomočjo ekonometrične analize preveriti določene teoretično utemeljene ekonomske, politične, družbene, demografske in kulturne dejavnike, ki naj bi povzročali razlike v velikosti javnega sektorja med državami, pri čemer se analiza usmerja tako na velikost "fiskalnega " dela javnega sektorja, merjenega $z$ deležem posamezne kategorije javnih izdatkov $v$ bruto domačem proizvodu, kot "nefiskalnega" oz. "tihega" dela javnega sektorja, merjenega $z$ makro obsegom regulacije zasebnega sektorja. Splošna ugotovitev analize je, da so ekonomski dejavniki pomembnejši pri analizi obsega regulacije in javnih izdatkov za nakupe dobrin in storitev, medtem ko so drugi dejavniki pomembnejši pri analizi transfernih izdatkov. Ena izmed pomembnejših ugotovitev analize je tudi, da se velikosti fiskalnega dela in nefiskalnega dela javnega sektorja gibljeta v nasprotni smeri.
\end{abstract}

Ključne besede: velikost javnega sektorja, fiskalni in nefiskalni del javnega sektorja, dejavniki velikosti, empirična analiza.

\section{Uvod}

$\checkmark$ zadnjem stoletju, še posebej pa $\vee$ zadnjih desetletjih, je velikost javnega sektorja, merjeno z deležem zajetega bruto domačega proizvoda, $\vee$ večini razvitih kapitalističnih držav narasla. Poleg rasti se je $\vee$ zadnjih desetletjih spremenila tudi struktura izdatkov, saj so najbolj naraščali transferni izdatki, namenjeni financiranju programov t. i. države blaginje. Pojav naraščanja velikosti javnega sektorja je v ekonomski literaturi relativno dobro analiziran, saj so se oblikovale številne hipoteze in zakoni (npr. Wagnerjeva hipoteza, Wilenskyjeva hipoteza, Cameronov zakon itd.) in modeli (npr. model Leviatana, model fiskalne iluzije, model političnih omejitev itd.), ki vsak na svoj način utemeljujejo naraščanje velikosti javnega sektorja (glej Lane, 1995; Tanzi in Schuknecht, 2000; Bailey, 2002). Kljub vsemu ostaja eno glavnih vprašanj, zakaj naraščanje velikosti javnega sektorja ni bilo enakomerno med državami, kar je skupaj z začetnimi razlikami povzročilo razlike $v$ velikosti javnega sektorja med državami. V letu 2000 so npr. javni izdatki zajemali približno 21 \% BDP v Južni Koreji, 37 \% v Veliki Britaniji, na Švedskem in Danskem pa celo 


\section{Dejavniki razlik v velikosti fiskalnega in nefiskalnega dela javnega sektorja}

več kot 50 \% BDP (OECD, 2001). Tako je namen prispevka analizirati, zakaj navedene razlike obstajajo in ugotoviti dejavnike, ki jih povzročajo. Drugače povedano, vprašanje je, kateri so razlogi, da je ena država v ekonomskem smislu bolj »laissez-faire» kot druga.

\section{Velikost javnega sektorja - fiskalni in nefiskalni vidik'}

$\checkmark$ praksi obstajajo številni načini merjenja velikosti javnega sektorja. Tako se lahko velikost meri s številom zaposlenih $v$ javnem sektorju ali s številom organizacijskih enot, vendar so merilci velikosti ponavadi naravnani bolj finančno (proračunsko), med njimi pa največkrat prevladujeta delež celotnih javnih izdatkov $v$ BDP in delež javnih izdatkov za nakupe dobrin in storitev $\vee$ BDP. ${ }^{2}$ Prednost takšnega načina merjenja velikosti je, da je ta izražena v eni sami številki. Po drugi strani je pomanjkljivost takšnega pristopa $\vee$ tem, da se pri merjenju upošteva samo fiskalni vidik državnega intervencionizma, saj se upoštevajo le tisti instrumenti in aktivnosti, ki se odražajo $v$ finančnih tokovih, izkazanih $v$ bilancah javnega financiranja. To je problematično, saj so fiskalni instrumenti samo ena oblika instrumentov izvajanja javnih politik, druga oblika instrumentov je namreč regulacija (Posner, 1971). Ta t. i. "tihi« oz. "nefiskalni« del javnega sektorja implicitno povečuje velikost javnega sektorja, saj so učinki regulacije enakovredni učinkom fiskalnih instrumentov, vendar se njihov vpliv ne vidi v bilancah javnega financiranja. ${ }^{\mathbf{3}}$

\subsection{Fiskalni vidik javnega sektorja}

Omenili smo že, da je literatura, povezana z analiziranjem dejavnikov, ki so vplivali na rast velikosti javnega sektorja, precej obsežna. Po drugi strani pa je zaznati pomanjkanje literature, ki bi analizirala razlike $v$ velikosti javnega sektorja med državami, zaradi česar se $v$ praksi še ni uveljavila obsežna in splošno sprejeta ekonomska teorija oblasti. Obstoječa literatura s tega področja se ukvarja pretežno

1 Za obširnejšo teoretično razlago in razlago obširnejše empirične analize glej Pevcin (2004).

2 Nekateri avtorji uporabljajo kot merilec velikosti javnega sektorja tudi delež izdatkov centralnih oblasti v BDP (angl. central government expenditure), vendar je uporaba tega merilca lahko precej problematična, saj podcenjuje velikost javnega sektorja $v$ državah, $v$ katerih se precej funkcij javnega sektorja izvaja tudi na lokalni ravni.

3 Dejstvo je, da ravno prisotnost nefiskalnih instrumentov državnega intervencionizma $\vee$ končni fazi vpliva na to, ali imajo v neki državi velik ali majhen javni sektor, saj ima lahko »Leviatan « preko regulacije dolge tipalke, ki pa jih je težko zaznati. V tem kontekstu Armey (1995, str. 316) opozarja, da je poleg dobro uveljavljenega koncepta "nevidne roke" na trgu treba spoznati še politično-ekonomski koncept "nevidne noge" države, ki ponazarja možnost, da država s presežno regulacijo in javnimi izdatki zavira ekonomski napredek. 
Primož Pevcin

Dejavniki razlik v velikosti fiskalnega in nefiskalnega dela javnega sektorja

$z$ analizo politično-ekonomskih dejavnikov, ki povzročajo razlike $v$ velikosti fiskalnega dela javnega sektorja, med katere sodijo:

- Velikost države, odprtost gospodarstva in stopnja vključenosti $v$ svetovno gospodarstvo.

Alesina in Wacziarg (1998, str. 306) trdita, da je obseg javnih izdatkov kot del BDP negativno povezan z velikostjo države in pozitivno povezan z ekonomsko odprtostjo države. Poleg tega trdita, da se njune empirične ugotovitve ujemajo s teoretičnimi modeli, ki utemeljujejo oblikovanje in razpad državnih tvorb. Skladno s temi modeli si namreč večje države lahko privoščijo, da so bolj zaprte zaradi večjega domačega trga. Poleg tega liberalizacija trgovine povzroča, da kulturne, etnične in regionalne manjšine težijo $k$ samostojnosti, ker se politične meje ne ujemajo več $z$ velikostjo trga. ${ }^{4}$ Prav tako je Rodrik (1998, str. 997) ugotovil močno pozitivno povezanost med odprtostjo gospodarstva in velikostjo javnega sektorja, kar je na nek način paradoks, saj v praksi pogosto velja, da so zaprta gospodarstva bolj intervencionistična, kar naj bi bilo vidno samo po sebi že iz omejevanja trgovine. Rodrik ta paradoks razlaga z dejstvom, da javni izdatki pogosto služijo kot orodje za izvajanje družbenega zavarovanja proti tveganju, povezanem s spremembami pogojev trgovanja, s katerimi se srečujejo odprta gospodarstva. Implicitno to pomeni, da mednarodni gospodarski liberalizem daje javnemu sektorju osrednjo ekonomsko vlogo, kar Ruggie (1982, str. 393) imenuje »uravnavajoči kompromis liberalizma«. Podobno Eichner in Wagener (2002, str. 19) trdita, da optimalna velikost države blaginje narašča s številom tveganj, proti katerim se ni mogoče zavarovati, kar je $v$ nasprotju s klasičnimi liberalnimi pričakovanji, da bo kombinacija globalizacije in tehnološke revolucije preoblikovala vlogo javnega sektorja nazaj v vlogo nočnega čuvaja. ${ }^{\mathbf{5}}$

- Ekonomska razvitost države in heterogenost volivcev/davkoplačevalcev. Skladno z Wagnerjevo in Wilenskyjevo hipotezo naj bi razvitost države pozitivno vplivala na javne izdatke. Splošno prepričanje je tudi, da naj bi stopnja urbanizacije pozitivno vplivala na raven javnega financiranja, predvsem $v$ povezavi z dejstvom, da večja gostitev prebivalstva vpliva na večje povpraševanje po nekaterih javnih in infrastrukturnih dobrinah.

4 Teoretsko področje oblikovanja in razpada držav postaja vse pomembnejše področje javne ekonomike. V enem zadnjih tekstov Alesina, Spolaore in Wacziarg (2003) ugotavljajo, da ekonomske koristi, povezane z velikostjo države, padajo v povezavi z naraščajočimi stroški nehomogenosti, kar pomeni, da optimalna velikost držav upada s stopnjo odprtosti gospodarstva. To pomeni, da lahko manjše države uživajo koristi kulturne homogenosti brez ekonomskih stroškov, povezanih z manjšim trgom.

$5 \mathrm{~V}$ tem kontekstu Wolf (2001, str. 143) trdi, da je kljub vsemu možnost naraščanja velikosti javnega sektorja precej omejena, saj naj bi Leviatan po splošnem prepričanju že dosegel zgornjo mejo. 


\section{Dejavniki razlik v velikosti fiskalnega in nefiskalnega dela javnega sektorja}

Poleg tega Holsey in Borcherding (1997) ugotavljata, da delež odvisne oz. vzdrževane populacije pozitivno vpliva na javne izdatke, predvsem $v$ povezavi z večjim povpraševanjem po izobraževalnih, zdravstvenih in socialnih storitvah. Na obseg javnih izdatkov naj bi vplivala tudi porazdelitev dohodka $\vee$ družbi. $\vee$ družbah z bolj neenakomerno porazdelitvijo dohodka, naj bi bil namreč sredinski volivec revnejši od povprečnega volivca, zato so koristi sredinskega volivca, povezane s prerazdeljevanjem dohodka, večje od stroškov, povezanih z večjo obdavčitvijo, zato takšen volivec odobrava prerazdelitveno politiko države (Persson in Tabellini, 1999).

- Struktura oblasti in vpliv političnih institucij ter zaposlenost $v$ javnem sektorju.

$\checkmark$ primeru mobilnosti davkoplačevalcev/volivcev lahko politično decentralizirana struktura oblasti prispeva k zmanjšanju velikosti javnega sektorja, saj decentralizirane enote tekmujejo za volivce, s čimer se povečuje njihova učinkovitost. Vendar pa po drugi strani financiranje lokalnih oblasti s strani centralnih oblasti povzroča zarotniško obnašanje lokalnih oblasti in njihovo napihovanje potreb po financah, s čimer se povečuje tudi velikost javnega sektorja (de Mello, 1999). Vpliv na javne izdatke naj bi imele tudi politične institucije, predvsem dveh izmed temeljnih dimenzij, to sta volilni sistem (večinski ali proporcionalni) in politični režim (predsedniški ali parlamentarni). Tako Persson (2001) trdi, da naj bi imele države s predsedniškim političnim režimom manjši javni sektor, večinski volilni sistem pa naj bi vplival na manjši delež programov, povezanih z zagotavljanjem storitev države blaginje. Poleg tega naj bi na obseg javnih izdatkov pozitivno vplival tudi delež zaposlenih v javnem sektorju, saj so ponavadi plače zaposlenih $\vee$ javnem sektorju predstavljajo pomembna postavko javnih izdatkov.

- Družbena razslojenost in etnična heterogenost družbe.

Ta skupina dejavnikov naj bi imela dva nasprotujoča si učinka. Po eni strani Annett (2000) ugotavlja, da večja družbena razslojenost eksogeno vodi v večjo politično nestabilnost, kar oblast skuša reševati z večjimi javnimi izdatki. Tako naj bi bil učinek družbene razslojenosti na javne izdatke pozitiven, vendar posreden preko kazalca politične nestabilnosti družbe. Po drugi strani pa Alesina, Glaeser in Sacerdote (2001) ugotavljajo, da naj bi bila predvsem stopnja intenzivnosti izvajanja socialne politike odvisna od rasne in etnične homogenosti družbe, pri čemer naj bi večja homogenost vplivala na intenzivnejše izvajanje te politike zaradi večje tolerantnosti volivcev do socialno ogroženih, ker je večja verjetnost, da socialno ogroženi pripadajo isti etnični skupini. 


\section{Primož Pevcin \\ Dejavniki razlik v velikosti fiskalnega in nefiskalnega dela javnega sektorja}

\subsection{Nefiskalni vidik javnega sektorja}

Nefiskalni del javnega sektorja sestavljajo aktivnosti, ki niso neposredno finančno izražene in vidne $v$ bilancah javnega financiranja, kljub temu pa zasebnemu sektorju povzročajo stroške oz. ekonomsko obremenitev. Nefiskalni instrumenti aktivnosti države se ponavadi pojavljajo $v$ obliki regulatornih zahtev, s katerimi se nadzira in usmerja delovanje posameznih ekonomskih subjektov, pri čemer OECD $(1997$, str. 6) v splošnem loči ekonomsko, socialno in administrativno regulacijo. ${ }^{6}$ Dejstvo je, da v ekonomski literaturi ne obstaja splošno sprejeta teorija o makro dejavnikih regulacije, pri čemer je treba omeniti tudi to, da se $v$ literaturi ponavadi analizira samo panožna regulacija, predvsem $v$ povezavi $z$ analizo naravnih monopolov, zunanjih učinkov in strateških dejavnosti. Pryor (2002) je eden redkih avtorjev, ki je poskušal opredeliti makro dejavnike regulacije, pri čemer mu je uspelo definirati nekaj smiselnih makroekonomskih dejavnikov regulacije: ${ }^{7}$

- Velikost gospodarstva.

Pryor ugotavlja, da naj bi imel ta dejavnik dva nasprotujoča si učinka. Po eni strani naj bi namreč velikost gospodarstva omejevala sposobnost učinkovitega reguliranja gospodarstva, vendar po drugi strani velikost gospodarstva implicira tudi velikost podjetij, ki naj bi bila večja $\vee$ večjih gospodarstvih in zato potrebnejša regulacije, predvsem z vidika omejevanja neželenih družbenih učinkov in ekonomske moči velikih korporacij.

- Ekonomska razvitost države.

Splošno prepričanje je, da naj bi obseg regulacije naraščal z razvitostjo gospodarstva, ker naj bi imela oblast za njeno izvajanje na razpolago več resursov, vendar po drugi strani Pryor ugotavlja, da razvitost implicira tudi večjo kompleksnost gospodarstva, ki povzroča neučinkovitost njenega izvajanja.

- Odprtost gospodarstva.

Splošno prepričanje je, da večja odprtost gospodarstva omejuje možnost in sposobnost oblasti za reguliranje gospodarstva, torej naj bi bil vpliv ravno nasproten kot pri fiskalnih instrumentih.

- Porazdelitev dohodka v družbi.

Neenakomernejša porazdelitev dohodka naj bi negativno vplivala na obseg regulacije, saj naj bi $\vee$ takem primeru bogatejše skupine volivcev imele relativno več politične moči, zaradi česar lahko omejujejo sprejemanje regulacije za svoje ekonomske aktivnosti.

6 Omeniti je treba, da obstajajo tudi druge delitve regulacije. Tako npr. Pryor (2002) loči panožno, pravno-zakonodajno, splošno ekonomsko in administrativno regulacijo.

$7 \vee$ Pryorjevi analizi sta statistično potrditev dobila samo dva dejavnika, to je velikost gospodarstva in porazdelitev dohodka, pri čemer rezultati analize kažejo, da je stopnja ekonomskega laissez-faire obratno povezana z velikostjo gospodarstva in pozitivno povezana z neenakostjo dohodka, kar naj bi bil celo ključni dejavnik regulacije. 


\section{Dejavniki razlik v velikosti fiskalnega in nefiskalnega dela javnega sektorja}

- Državno lastništvo podjetij.

Večina ekonomistov ima regulacijo in državno lastništvo podjetij za substituta, predvsem v povezavi s splošnim prepričanjem, da morajo biti privatna podjetja bolj regulirana zaradi preprečevanja izkoriščanja njihove eventualne tržne moči. Vendar Pryor trdi, da naj bi bila državno lastništvo podjetij in regulacija komplementa, saj sta oba instrumenta vzpostavljena $z$ istim namenom nadzora nad aktivnostmi zasebnega sektorja.

\section{Empirična analiza dejavnikov velikosti javnega sektorja}

\subsection{Podatki in metodologija}

Osnovni namen prispevka je opredeliti možne ekonomske, politične, družbene, demografske in kulturne dejavnike, ki povzročajo razlike $v$ velikosti javnega sektorja med državami, ter preveriti njihovo statistično veljavnost s pomočjo multiple regresijske analize presečnih podatkov na izbranem vzorcu 32 držav. ${ }^{\mathbf{8}}$ Na splošno lahko ugotovimo, da obstajajo posamezni skupni dejavniki, ki vplivajo na razlike $\vee$ velikosti fiskalnega in nefiskalnega dela javnega sektorja; edina skupina dejavnikov, ki nimajo racionalne podlage za vpliv na nefiskalni del javnega sektorja, je skupina demografskih dejavnikov, zato ti niso vključeni $v$ analizo dejavnikov razlik $\checkmark$ velikosti nefiskalnega dela javnega sektorja.

$\checkmark$ analizi nastopajo kot odvisne spremenljivke delež izdatkov za nakup dobrin in storitev $\vee$ BDP (CON), delež transfernih izdatkov $\vee$ BDP (TRF) in delež celotnih javnih izdatkov $\vee$ BDP (EXP) kot kazalci velikosti fiskalnega dela javnega sektorja ${ }^{\mathbf{9}}$ ter indeks celotne regulacije gospodarstva (REG) kot indikator velikosti nefiskalnega dela javnega sektorja. Kot pojasnjevalne spremenljivke pa $v$ analizi nastopajo:

- Realni bruto domači proizvod na prebivalca (GDPC).

Pričakovati je, da bo skladno z Wagnerjevo in Wilenskyjevo hipotezo spremenljivka pozitivno vplivala na razlike $\vee$ velikosti fiskalnega dela javnega sektorja, medtem ko je njen skupni učinek na razlike $v$ obsegu regulacije odvisen od tega, kateri od prej omenjenih nasprotujočih si vplivov bo prevladal.

8 Vzorec vključuje 27 držav članic organizacije OECD (od 30 držav članic zaradi pomanjkanja razpoložljivih podatkov niso vključene Islandija, Japonska in Turčija), 4 razvite tranzicijske države nečlanice OECD (Estonija, Latvija, Litva in Slovenija) ter Čile kot eno izmed novoindustrializiranih držav v Latinski Ameriki.

9 Namen uporabe treh kazalcev velikosti fiskalnega dela javnega sektorja je opozoriti na možne različne smeri vpliva pojasnjevalnih spremenljivk na dva glavna elementa javnih izdatkov, ki ju $\vee$ večini držav tvorijo izdatki za nakupe dobrin in storitev ter transferni izdatki. 
- Velikost države (POP) in ekonomska odprtost države (OPN).

Pričakovati je, da bo spremenljivka POP negativno vplivala na obseg javnih izdatkov, predvsem zaradi ekonomij obsega in večje tehnične učinkovitosti javnega financiranja $v$ večjih državah, medtem ko naj bi bil njen vpliv na obseg regulacije zaradi nasprotujočih si učinkov nejasen. Po drugi strani je pričakovati pozitiven vpliv ekonomske odprtosti na obseg javnih izdatkov ter negativen vpliv na obseg regulacije.

- Delež prebivalstva, starejšega od 65 let (OLD), in delež prebivalstva, mlajšega od 19 let (YOU) - vzdrževano prebivalstvo.

Ekonomska teorija priznava negativne učinke staranja prebivalstva, ki vključujejo tudi naraščajoče povpraševanje po zdravstvenih storitvah, socialni varnosti itd. Poleg tega pa po drugi strani velik delež prebivalstva, mlajšega od 19 let, implicira večje povpraševanje po izobraževalnih storitvah, zato lahko pričakujemo, da bosta oba dejavnika pozitivno vplivala na obseg javnih izdatkov.

- Stopnja urbaniziranosti države (URB).

Večja urbanizacija naj bi pozitivno vplivala na javne izdatke, predvsem na javne izdatke za nakupe dobrin in storitev, ker je povpraševanje po javnih dobrinah in storitvah ponavadi večje ravno $\vee$ urbanih sredinah. Po drugi strani ni pričakovati vpliva te spremenljivke na obseg regulacije.

- Obseg državnega lastništva podjetij (OWN).

Pričakovati je, da bo državno lastništvo podjetij implicitno vplivalo tudi na javne izdatke, saj so podjetja $\vee$ državni lasti prvenstveno zato, da proizvajajo določene (javne) dobrine in storitve, katerih glavni kupec je ponavadi država. To pomeni, da naj bi obseg državnega lastništva podjetij pozitivno vplival na javne izdatke. Pričakovati je tudi pozitiven vpliv na obseg regulacije, saj naj bi večje število državnih podjetij vplivalo tudi na večje število regulatornih teles, ta učinek pa naj bi se poleg tega kazal tudi v večjih javnih izdatkih.

- Delež delovne sile, zaposlene v državni administraciji (GEMP). Glede na to, da so plače državnih uslužbencev pomemben segment javnih izdatkov, je pričakovati njihov pozitiven vpliv na obseg javnih izdatkov.

- Porazdelitev dohodka v družbi (GINI).

Ena izmed predpostavk $v$ politično-ekonomski literaturi je, da naj bi bili javni izdatki večji $v$ državah z relativno večjo neenakostjo $v$ porazdelitvi dohodka, saj to implicira, da je sredinski volivec revnejši od povprečnega volivca. To pomeni, da naj bi večje vrednosti Ginijevega koeficienta pozitivno vplivale na javne izdatke. Po drugi strani je pričakovati, da bo večja neenakost $v$ porazdelitvi dohodka negativno vplivala na obseg regulacije $\vee$ gospodarstvu zaradi večje politične moči bogatejših skupin posameznikov.

- Delež največje etnične skupine v celotni populaciji (FRAGM).

Navedena spremenljivka izraža etnično in kulturno homogenost $v$ družbi, imela pa naj bi dva nasprotujoča si učinka. Po eni strani je namreč $v$ bolj homogenih družbah politična nestabilnost ponavadi manjša, kar implicira tudi manjše javne izdatke za blažitev potencialne in dejanske nestabilnosti. 


\section{Dejavniki razlik v velikosti fiskalnega in nefiskalnega dela javnega sektorja}

Po drugi strani je pričakovati, da bo družbena homogenost pozitivno vplivala na javne izdatke, saj je pričakovati, da v takem primeru volivci lažje sprejemajo večje izdatke, namenjene posamezni socialni skupini, predvsem zato, ker je manjša verjetnost, da večina predstavnikov posamezne socialne skupine pripada neki etnični oz. kulturni manjšini. Navedeni učinek temelji na predpostavki, da je v človeški naravi, da lažje sprejemajo ljudi, ki so iste vrste.

- Vpliv političnih institucij, ki ga odražajo tri binarne neprave spremenljivke, in sicer obstoj predsedniškega političnega režima (PRES), večinskega volilnega sistema (MAJ) in organiziranost države po načelih politične decentraliziranosti (FED).

Pričakovati je, da bo obstoj predsedniškega političnega režima negativno vplival na javne izdatke ter pozitivno vplival na obseg regulacije predvsem z učinkom dohodka in učinkom odprtosti. ${ }^{\mathbf{1 0}}$ Po drugi strani naj bi obstoj večinskega volilnega sistema pozitivno vplival na izdatke za nakupe dobrin in storitev, negativno vplival na transferne izdatke ter pozitivno vplival na obseg regulacije z že prej omenjenima učinkoma dohodka in substitucije. Poleg tega je pričakovati, da bo politična decentralizacija pozitivno vplivala tako na javne izdatke kot na regulacijo, saj vsaka dodatna raven oblasti implicira dodatne stroške delovanja ter izvaja neko obliko državnega intervencionizma. ${ }^{11}$

- Vpliv kulturnih dejavnikov, ki ga odražajo tri binarne slamnate spremenljivke za azijske države (ASIA), zahodnoevropske države (WEU) in tranzicijske države (TRA).

Namen uporabe teh spremenljivk $v$ analizi je zaznati možne kulturne in institucionalne razlike, ki bi povzročale različne povprečne velikosti javnega sektorja $v$ teh treh regijah. Pričakovati je namreč, da bodo imele azijske države $\vee$ povprečju manjše javne izdatke zaradi kulturnih vrednot, ki promovirajo večjo socialno vlogo družine. Po drugi strani je pričakovati, da bodo imele zahodnoevropske države $\vee$ povprečju večje javne izdatke zaradi vgrajenega individualizma in socialnosti $\vee$ delovanje teh družb, ki pogosto pripisujeta družini le marginalno ekonomsko in socialno vlogo. Namen uvedbe posebne spremenljivke za tranzicijske države je predvsem zaznati možne učinke, povezane s spremembo družbeno-ekonomskega sistema, ki je precej zmanjšala ekonomsko vlogo države, kljub vsemu pa je pričakovati, da ostanki prejšnjega režima implicirajo večjo vlogo javnega sektorja $\vee$ teh državah, predvsem kar se tiče velikosti nefiskalnega dela.

10 Pevcin (2004) je s pomočjo regresijskega modela Probit pokazal, da obstaja večja verjetnost, da imajo bolj odprta in razvitejša gospodarstva parlamentarni politični režim in proporcionalni volilni sistem.

11 Več o tem glej Pevcin, 2003 in 2004. 
Primož Pevcin

Dejavniki razlik v velikosti fiskalnega in nefiskalnega dela javnega sektorja

Tabela 1: Opis spremenljivk in viri podatkov ${ }^{12}$

\begin{tabular}{|c|c|c|}
\hline $\begin{array}{l}\text { Oznaka } \\
\text { spremen- } \\
\text { ljivke }\end{array}$ & Opis & Vir podatkov \\
\hline CON & $\begin{array}{l}\text { javni izdatki za nakupe dobrin in storitev oz. } \\
\text { potrošni izdatki (\% BDP) }\end{array}$ & $\begin{array}{l}\text { World Development } \\
\text { Indicators (2001) }\end{array}$ \\
\hline TRF & transferni javni izdatki (\% BDP) & $\begin{array}{l}\text { Gwartney in Lawson } \\
(2002)\end{array}$ \\
\hline EXP & celotni javni izdatki (\% BDP) & $\begin{array}{l}\text { OECD (2001), EBRD } \\
(2001)\end{array}$ \\
\hline GDPC & realni bruto domači proizvod na prebivalca (v USD) & $\begin{array}{l}\text { World Development } \\
\text { Indicators (2001) }\end{array}$ \\
\hline OPN & ekonomska odprtost (delež izvoza in uvoza v \% BDP) & $\begin{array}{l}\text { World Development } \\
\text { Indicators (2002) }\end{array}$ \\
\hline POP & velikost države (število prebivalcev v mio.) & $\begin{array}{l}\text { World Development } \\
\text { Indicators (2002) }\end{array}$ \\
\hline OLD & $\begin{array}{l}\text { delež prebivalstva, starejšega od } 65 \text { let, } \\
\text { v celotni populaciji (\%) }\end{array}$ & U. S. Census (2001) \\
\hline YOU & $\begin{array}{l}\text { delež prebivalstva, mlajšega od } 19 \text { let, } \\
\text { v celotni populaciji }(\%)\end{array}$ & U. S. Census (2001) \\
\hline OWN & $\begin{array}{l}\text { državno lastništvo podjetij, politomna slamnata } \\
\text { spremenljivka, od } 0 \text { (min.) do } 10 \text { (maks.) }\end{array}$ & $\begin{array}{l}\text { Povzeto po Gwartney in } \\
\text { Lawson (2002) }\end{array}$ \\
\hline REG & $\begin{array}{l}\text { makro obseg (ekonomske, socialne in administrativne) } \\
\text { regulacije gospodarstva, politomna spremenljivka, } \\
\text { vrednosti od } 0 \text { (min.) do } 10 \text { (maks.) }\end{array}$ & $\begin{array}{l}\text { Povzeto po Gwartney in } \\
\text { Lawson (2002) }\end{array}$ \\
\hline URB & $\begin{array}{l}\text { stopnja urbaniziranosti države (delež prebivalstva, } \\
\text { živečega v urbanih naseljih, v celotni populaciji - \%) }\end{array}$ & $\begin{array}{l}\text { World Development } \\
\text { Indicators (2002) }\end{array}$ \\
\hline PRES & $\begin{array}{l}\text { politični režim, dihotomna slamnata spremenljivka, } \\
1(0) \text { - predsedniški (parlamentarni) politični režim }\end{array}$ & Beck idr. (2001) \\
\hline PLUR & $\begin{array}{l}\text { volilni sistem, dihotomna slamnata spremenljivka, } \\
1(0) \text { - večinski (proporcionalni) volilni sistem }\end{array}$ & $\begin{array}{l}\text { Elections around the } \\
\text { world (2003) }\end{array}$ \\
\hline FED & $\begin{array}{l}\text { struktura oblasti, dihotomna slamnata spremenljivka, } \\
1 \text { - politična decentralizacija (lokalna oblast ima } \\
\text { pomemben vpliv na obseg svoje fiskalne in nefiskalne } \\
\text { aktivnosti) }\end{array}$ & Beck idr. (2001) \\
\hline FRAGM & $\begin{array}{l}\text { homogenost družbe (delež največje etnične oz kultur- } \\
\text { ne skupine v celotni populaciji, \%) }\end{array}$ & $\begin{array}{l}\text { Encarta Encyclopedia } \\
\text { (2003) }\end{array}$ \\
\hline GEMP & $\begin{array}{l}\text { zaposlenost } v \text { javnem sektorju } \\
\text { (\% celotne delovne sile) }\end{array}$ & $\begin{array}{l}\text { Schiavo-Campo idr. } \\
\text { (1997) }\end{array}$ \\
\hline GINI & Ginijev koeficient porazdelitve dohodka & $\begin{array}{l}\text { World Development } \\
\text { Indicators (2000) }\end{array}$ \\
\hline
\end{tabular}

12 Vse spremenljivke se nanašajo na leto 2000 oz. najbližje razpoložljivo leto (npr. podatki za spremenljivko GEMP se nanašajo na leto 1995, za kasnejša leta pa mednarodno primerljivi in dostopni podatki ne obstajajo). 


\section{Dejavniki razlik v velikosti fiskalnega in nefiskalnega dela javnega sektorja}

\subsection{Rezultati analize}

$\checkmark$ nadaljevanju so prikazani rezultati empirične analize dejavnikov velikosti oz. razlik $\vee$ velikosti fiskalnega in nefiskalnega dela javnega sektorja na izbranem vzorcu razvitih in demokratičnih držav. Regresijska analiza temelji na obdelavi presečnih podatkov, pri čemer OLS označuje metodo navadnih najmanjših kvadratov, White HC označuje regresijski model OLS, prilagojen za heteroskedastičnost, NeweyWest HAC pa regresijski model, prilagojen za heteroskedastičnost in avtokorelacijo. ${ }^{\mathbf{1 3}}$

Tabela 2: Dejavniki razlik v obsegu javnih izdatkov za nakupe dobrin in storitev

\begin{tabular}{|c|c|c|c|}
\hline $\begin{array}{l}\text { Odvisna } \\
\text { spremenljivka CON }\end{array}$ & OLS & $\begin{array}{l}\text { OLS } \\
\text { (White HC) }\end{array}$ & $\begin{array}{l}\text { OLS } \\
\text { (Newey-West HAC) }\end{array}$ \\
\hline CONST & $\begin{array}{r}2.6391 \\
(0.73,0.4704)\end{array}$ & $\begin{array}{r}2.6391 \\
(0.79,0.4366)\end{array}$ & $\begin{array}{r}2.6391 \\
(0.73,0.4697)\end{array}$ \\
\hline GEMP & $\begin{array}{r}0.1590 \\
(1.88,0.0711) \\
\end{array}$ & $\begin{array}{r}0.1590 \\
(2.82,0.0090) \\
\end{array}$ & $\begin{array}{r}0.1590 \\
(3.36,0.0024) \\
\end{array}$ \\
\hline OLD & $\begin{array}{r}0.5549 \\
(3.26,0.0030)\end{array}$ & $\begin{array}{r}0.5549 \\
(4.59,0.0001)\end{array}$ & $\begin{array}{r}0.5549 \\
(4.97,0.0000)\end{array}$ \\
\hline URB & $\begin{array}{r}0.1053 \\
(2.74,0.0108) \\
\end{array}$ & $\begin{array}{r}0.1053 \\
(2.76,0.0104) \\
\end{array}$ & $\begin{array}{r}0.1053 \\
(2.44,0.0217) \\
\end{array}$ \\
\hline PLUR & $\begin{array}{r}-4.0348 \\
(-4.03,0.0004) \\
\end{array}$ & $\begin{array}{r}-4.0348 \\
(-3.64,0.0011) \\
\end{array}$ & $\begin{array}{r}-4.0348 \\
(-4.00,0.0004) \\
\end{array}$ \\
\hline$N$ & 32 & 32 & 32 \\
\hline $\mathrm{R}_{\text {popr. }}^{2}$ & 0.6472 & 0.6472 & 0.6472 \\
\hline $\mathrm{s}_{\mathrm{e}}$ & 2.56 & 2.56 & 2.56 \\
\hline F-stat. & 15.22 & 15.22 & 15.22 \\
\hline Heterosked. (OLS) & ne & l & / \\
\hline
\end{tabular}

Vir: lastni izračuni.

Rezultati v zgornji tabeli kažejo, da delež zaposlenih v državni administraciji, delež prebivalstva, starejšega od 65 let, in stopnja urbaniziranosti države pozitivno vplivajo na obseg javnih izdatkov za nakupe dobrin in storitev, kar je v skladu s teoretičnimi pričakovanji, medtem ko naj bi prisotnost večinskega volilnega

$13 \vee$ oklepajih $v$ tabelah so prikazane vrednosti t-statistike in natančne stopnje značilnosti, pri čemer so $v$ tabelah prikazane samo statistično značilne spremenljivke. Metoda izločevanja spremenljivk temelji na njihovi statistični neznačilnosti in dejstvu, ali njihova prisotnost v modelu samo "napihuje « varianco. 
Primož Pevcin

Dejavniki razlik v velikosti fiskalnega in nefiskalnega dela javnega sektorja

sistema negativno vplivala na obseg javnih izdatkov za nakupe dobrin in storitev, kar je $v$ nasprotju s teoretičnimi pričakovanji. ${ }^{\mathbf{1 4}}$

Tabela 3: Dejavniki razlik v obsegu transfernih izdatkov

\begin{tabular}{|c|c|c|c|}
\hline $\begin{array}{l}\text { Odvisna } \\
\text { spremenljivka TRF }\end{array}$ & OLS & $\begin{array}{l}\text { OLS } \\
\text { (White HC) }\end{array}$ & $\begin{array}{l}\text { OLS } \\
\text { (Newey-West HAC) }\end{array}$ \\
\hline \multirow{2}{*}{ CONST } & 4.5926 & 4.5926 & 4.5926 \\
\hline & $(0.75,0.4630)$ & $(0.83,0.4141)$ & $(0.96,0.3440)$ \\
\hline \multirow{2}{*}{ OPN } & 0.0526 & 0.0526 & 0.0526 \\
\hline & $(2.39,0.0249)$ & $(3.19,0.0038)$ & $(3.16,0.0041)$ \\
\hline \multirow{2}{*}{ PLUR } & -6.1494 & -6.1494 & -6.1494 \\
\hline & $(-3.24,0.0034)$ & $(-3.90,0.0006)$ & $(-3.46,0.0020)$ \\
\hline \multirow{2}{*}{ FED } & 9.2701 & 9.2701 & 9.2701 \\
\hline & $(4.48,0.0001)$ & $(3.29,0.0030)$ & $(2.61,0.0152)$ \\
\hline \multirow{2}{*}{ FRAGM } & 0.2252 & 0.2252 & 0.2252 \\
\hline & $(3.77,0.0009)$ & $(3.49,0.0018)$ & $(3.35,0.0025)$ \\
\hline \multirow{2}{*}{ REG } & -3.3807 & -3.3807 & -3.3807 \\
\hline & $(-3.00,0.0061)$ & $(-2.86,0.0085)$ & $(-2.82,0.0093)$ \\
\hline \multirow{2}{*}{ TRA } & 5.7308 & 5.7308 & 5.7308 \\
\hline & $(2.39,0.0247)$ & $(2.54,0.0178)$ & $(2.56,0.0168)$ \\
\hline $\mathrm{N}$ & 32 & 32 & 32 \\
\hline$R_{\text {popr. }}^{2}$ & 0.5403 & 0.5403 & 0.5403 \\
\hline $\mathrm{s}_{\mathrm{e}}$ & 4.3650 & 4.3650 & 4.3650 \\
\hline F-stat. & 7.07 & 7.07 & 7.07 \\
\hline Heterosked. (OLS) & ne & l & I \\
\hline
\end{tabular}

Vir: lastni izračuni.

Rezultati v tabeli 3 kažejo, da naj bi imele bolj odprte države večji delež transfernih izdatkov v BDP, kar je skladno z ugotovitvami Rodrika, da v ekonomsko bolj odprtih državah javni sektor zagotavlja družbeno zavarovanje proti spremembam pogojev trgovanja, s katerimi se te države srečujejo, pri čemer naj bi se to zavarovanje izvajalo ravno s transfernimi izdatki. Rezultati analize tudi kažejo, da imajo bolj homogene družbe večji delež transfernih izdatkov v BDP, kar pomeni, da se očitno volivci bolj strinjajo $z$ večjimi izdatki socialno ogroženim skupinam, če posamezniki

14 Problem pri analizi je $v$ tem, da je regresijska konstanta statistično neznačilna, kar nakazuje možnost, da v analizi manjka kakšna relevantna spremenljivka. 


\section{Dejavniki razlik v velikosti fiskalnega in nefiskalnega dela javnega sektorja}

$\checkmark$ teh skupinah bolj ali manj pripadajo isti (večinski) etnični oz. kulturni skupini. Skladno $s$ teoretičnimi pričakovanji so transferni izdatki negativno povezani $z$ obstojem večinskega volilnega sistema in pozitivno povezani s politično decentralizacijo, najverjetneje zaradi t. i. učinka muholovke (angl. fly-paper effect ${ }^{\mathbf{1 5}}$ ), ki nastane $\checkmark$ politično decentraliziranih državah zaradi transfernih plačil, ki jih centralne oblasti namenjajo lokalnim oblastem. Poleg tega je iz tabele razvidno, da so transferni izdatki v povprečju višji v tranzicijskih državah, predvsem zaradi številnih socialnih problemov, povezanih z ekonomsko in politično transformacijo $v$ teh državah. Sklepna ugotovitev je, da lahko s šestimi pojasnjevalnimi spremenljivkami razložimo več kot $50 \%$ variance obsega transfernih izdatkov, kar $v$ analizi presečnih podatkov ni slab rezultat. ${ }^{16}$ Po drugi strani pa je analiza celotnih javnih izdatkov (tabela 4) pokazala, da samo dve pojasnjevalni spremenljivki statistično značilno pojasnjujeta razlike $v$ obsegu javnih izdatkov med državami. Ti dve spremenljivki sta delež prebivalstva, starejšega od 65 let, in obstoj večinskega volilnega sistema. To očitno nakazuje, da je treba pri analizi dejavnikov obsega javnih izdatkov posebej analizirati posamezne kategorije javnih izdatkov.

Tabela 4: Dejavniki razlik v obsegu celotnih javnih izdatkov

\begin{tabular}{|c|c|c|c|}
\hline $\begin{array}{l}\text { Odvisna } \\
\text { spremenljivka EXP }\end{array}$ & OLS & $\begin{array}{l}\text { OLS } \\
\text { (White HC) }\end{array}$ & $\begin{array}{l}\text { OLS } \\
\text { (Newey-West HAC) }\end{array}$ \\
\hline CONST & $\begin{array}{r}17.8240 \\
(3.43,0.0018)\end{array}$ & $\begin{array}{r}17.8240 \\
(3.16,0.0036) \\
\end{array}$ & $\begin{array}{r}17.8240 \\
(3.09,0.0044)\end{array}$ \\
\hline OLD & $\begin{array}{r}1.8196 \\
(5.22,0.0000)\end{array}$ & $\begin{array}{r}1.8196 \\
(5.82,0.0000)\end{array}$ & $\begin{array}{r}1.8196 \\
(5.42,0.0000)\end{array}$ \\
\hline PLUR & $\begin{array}{r}-5.3468 \\
(-2.53,0.0172) \\
\end{array}$ & $\begin{array}{r}-5.3468 \\
(-2.32,0.0278) \\
\end{array}$ & $\begin{array}{r}-5.3468 \\
(-2.09,0.0455) \\
\end{array}$ \\
\hline $\mathrm{N}$ & 32 & 32 & 32 \\
\hline $\mathrm{R}_{\text {popr. }}^{2}$ & 0.5469 & 0.5469 & 0.5469 \\
\hline $\mathrm{S}_{\theta}$ & 5.89 & 5.89 & 5.89 \\
\hline F-stat. & 19.71 & 19.71 & 19.71 \\
\hline Heterosked. (OLS) & da (pri $10 \%)$. & l & I \\
\hline
\end{tabular}

Vir: Iastni izračuni

15 Glej Brennan in Pincus (1996).

16 Več o razlogih za to glej Gujarati (2002). 
Primož Pevcin

Dejavniki razlik v velikosti fiskalnega in nefiskalnega dela javnega sektorja

Tabela 5: Dejavniki razlik v obsegu regulacije

\begin{tabular}{|c|c|c|c|}
\hline $\begin{array}{l}\text { Odvisna } \\
\text { spremenljivka REG }\end{array}$ & OLS & $\begin{array}{l}\text { OLS } \\
\text { (White HC) }\end{array}$ & $\begin{array}{l}\text { OLS } \\
\text { (Newey-West HAC) }\end{array}$ \\
\hline CONST & $\begin{array}{r}7.6970 \\
(8.33,0.0000)\end{array}$ & $\begin{array}{r}7.6970 \\
(10.82,0.0000)\end{array}$ & $\begin{array}{r}7.6970 \\
(10.87,0.0000)\end{array}$ \\
\hline GDPC & $\begin{array}{r}-0.0000268 \\
(-2.40,0.0244)\end{array}$ & $\begin{array}{r}-0.0000268 \\
(-3.05,0.0056)\end{array}$ & $\begin{array}{r}-0.0000268 \\
(-3.25,0.0034)\end{array}$ \\
\hline GINI & $\begin{array}{r}-0.0906 \\
(-4.40,0.0002)\end{array}$ & $\begin{array}{r}-0.0906 \\
(-6.33,0.0000)\end{array}$ & $\begin{array}{r}-0.0906 \\
(-5.76,0.0000)\end{array}$ \\
\hline POP & $\begin{array}{r}-0.00435 \\
(-1.85,0.0769)\end{array}$ & $\begin{array}{r}-0.00435 \\
(-2.78,0.0104)\end{array}$ & $\begin{array}{r}-0.00435 \\
(-2.55,0.0174)\end{array}$ \\
\hline OWN & $\begin{array}{r}0.1149 \\
(2.51,0.0193)\end{array}$ & $\begin{array}{r}0.1149 \\
(3.33,0.0028)\end{array}$ & $\begin{array}{r}0.1149 \\
(3.82,0.0008)\end{array}$ \\
\hline PRES & $\begin{array}{r}1.1141 \\
(2.38,0.0257)\end{array}$ & $\begin{array}{r}1.1141 \\
(3.59,0.0015)\end{array}$ & $\begin{array}{r}1.1141 \\
(3.15,0.0043)\end{array}$ \\
\hline TRF & $\begin{array}{r}-0.0381 \\
(-2.34,0.0278)\end{array}$ & $\begin{array}{r}-0.0381 \\
(-3.13,0.0046)\end{array}$ & $\begin{array}{r}-0.0381 \\
(-3.52,0.0018)\end{array}$ \\
\hline GEMP & $\begin{array}{r}-0.0423 \\
(-2.65,0.0140)\end{array}$ & $\begin{array}{r}-0.0423 \\
(-2.63,0.0147)\end{array}$ & $\begin{array}{r}-0.0423 \\
(-2.34,0.0279)\end{array}$ \\
\hline$N$ & 32 & 32 & 32 \\
\hline $\mathrm{R}_{\text {popr. }}^{2}$ & 0.6910 & 0.6910 & 0.6910 \\
\hline $\mathrm{S}_{\mathrm{e}}$ & 0.4771 & 0.4771 & 0.4771 \\
\hline F-stat. & 10.90 & 10.90 & 10.90 \\
\hline Heterosked. (OLS) & ne & I & I \\
\hline
\end{tabular}

Vir: lastni izračuni

Tabela 5 prikazuje, da je modeliranje dejavnikov obsega regulacije očitno najlažje, saj je skoraj $70 \%$ variance obsega regulacije pojasnjene s sedmimi statistično značilnimi spremenljivkami. Rezultati namreč kažejo, da je obseg regulacije negativno 


\section{Dejavniki razlik v velikosti fiskalnega in nefiskalnega dela javnega sektorja}

povezan z neenakostjo porazdelitve dohodka $v$ družbi, s stopnjo gospodarske razvitosti družbe in z velikostjo države, kar potrjuje tezo, da je izvajanje regulatornih aktivnosti lažje $\vee$ manjših in manj razvitih državah. Poleg tega je obseg regulacije pozitivno povezan s stopnjo državnega lastništva podjetij (komplementaren odnos) in predsedniškim političnim režimom (razlog je verjetno dejstvo, da imajo ti režimi manjšo velikost fiskalnega dela javnega sektorja) ter negativno povezan z deležem zaposlenosti $\vee$ javnem sektorju in deležem transfernih izdatkov $\vee$ BDP, ${ }^{17}$ dvema kazalcema fiskalnih oz. "vidnih « aktivnosti javnega sektorja. ${ }^{\mathbf{1 8}}$

Omeniti velja, da $v$ analizi kot pojasnjevalni spremenljivki nastopata tudi spremenljivki CON in TRF kot merilca velikosti fiskalnega dela javnega sektorja. Pevcin (2004) namreč $v$ analizi razmerja med fiskalnim in nefiskalnim delom javnega sektorja na vzorcu 114 držav ugotavlja, da se velikost fiskalnega in nefiskalnega dela javnega sektorja giblje v nasprotni smeri - večji javni izdatki v BDP implicirajo manjši obseg regulacije (glej tudi tabelo 6). Kot možno razlago navedenega pojava navaja tezo, da regulacija nastopa kot neposreden substitut javnim izdatkom, saj majhen obseg javnih izdatkov implicira pomembno vlogo zasebnega sektorja $v$ gospodarstvu, oblast pa nadzira in usmerja njegovo delovanje z regulatornimi instrumenti. Tako naj bi v družbi obstajal t. i. transmisijski mehanizem državnega intervencionizma, ki pravi, da večja odprtost gospodarstva omejuje možnost njegove regulacije, kar spodbuja gospodarski napredek in $v$ končni fazi skladno z Wagnerjevo in Wilenskyjevo hipotezo povečuje tudi delež tako potrošnih kot transfernih izdatkov $\vee$ BDP. Obstoj navedenega transmisijskega mehanizma je mogoče razbrati tudi iz tabele 6 , ki prikazuje, da so razvitejše države bolj odprte in imajo večji delež potrošnih izdatkov v BDP, vendar je po drugi strani v teh državah manj regulacije in državnega lastništva podjetij. To pomeni, da nastopata regulacija in javni izdatki kot substituta, pri čemer naj bi ekonomski napredek impliciral manj regulacije in več javnih izdatkov. Posledično lahko transmisijski mehanizem napišemo v naslednji obliki:

$$
\mathrm{OPN} \uparrow \rightarrow \mathrm{REG} \downarrow \rightarrow \mathrm{GDP}_{\mathrm{PC}} \uparrow \rightarrow \mathrm{CON} \uparrow
$$

17 Metodološko gledano sta modela, ki pojasnjujeta spremenljivki REG in TRF, modela simultanih enačb, saj obe spremenljivki hkrati pojasnjujeta druga drugo, kar pomeni, da obstaja možnost obstoja simultanosti med njima, vendar je Hausmanov test napake specifikacije pokazal, da med navedenima spremenljivkama ni simultanosti, kar pomeni, da daje metoda regresijske analize OLS konsistentne in učinkovite ocene in ni potrebe po uporabi regresijske metode 2SLS (metoda dvostopenjskih najmanjših kvadratov).

18 Rezultati v tabeli 2 namreč kažejo, da spremenljivka GEMP pozitivno vpliva na CON, kar pomeni, da očitno spremenljivka GEMP »nadomešča» spremenljivko CON v razmerju do spremenljivke REG. 
Primož Pevcin

Dejavniki razlik v velikosti fiskalnega in nefiskalnega dela javnega sektorja

Tabela 6: Aktivnosti javnega sektorja in gospodarska razvitost

\begin{tabular}{|c|c|c|c|}
\hline $\begin{array}{l}\text { Odvisna } \\
\text { spremenljivka } \\
\text { LN (GDPC) }\end{array}$ & OLS & $\begin{array}{l}\text { OLS } \\
\text { (White HC) }\end{array}$ & $\begin{array}{l}\text { OLS } \\
\text { (Newey-West HAC) }\end{array}$ \\
\hline CONST & $\begin{array}{c}8.8040 \\
(13.81,0.0000)\end{array}$ & $\begin{array}{c}8.8040 \\
(12.91,0.0000)\end{array}$ & $\begin{array}{c}8.8040 \\
(14.10,0.0000)\end{array}$ \\
\hline CON & $\begin{array}{c}0.1078 \\
(5.64,0.0000)\end{array}$ & $\begin{array}{c}0.1078 \\
(5.57,0.0000)\end{array}$ & $\begin{array}{c}0.1078 \\
(5.05,0.0000)\end{array}$ \\
\hline OPN & $\begin{array}{c}0.00404 \\
(2.04,0.0440)\end{array}$ & $\begin{array}{c}0.00404 \\
(2.53,0-.0128)\end{array}$ & $\begin{array}{c}0.00404 \\
(2.16,0.0327)\end{array}$ \\
\hline OWN & $\begin{array}{c}-0.2134 \\
(-5.23,0.0000) \\
\end{array}$ & $\begin{array}{c}-0.2134 \\
(-6.58,0.0000)\end{array}$ & $\begin{array}{c}-0.2134 \\
(-6.73,0.0000)\end{array}$ \\
\hline REG & $\begin{array}{c}-0.4314 \\
(-3.14,0.0008)\end{array}$ & $\begin{array}{c}-0.4314 \\
(-3.40,0.0010)\end{array}$ & $\begin{array}{c}-0.4314 \\
(-4.16,0.0001)\end{array}$ \\
\hline $\mathrm{N}$ & 114 & 114 & 114 \\
\hline$R_{\text {popr. }}^{2}$ & 0.6005 & 0.6005 & 0.6005 \\
\hline $\mathrm{s}_{\mathrm{e}}$ & 1.03 & 1.03 & 1.03 \\
\hline F-stat. & 43.46 & 43.46 & 43.46 \\
\hline $\begin{array}{l}\text { Heterosked. } \\
\text { (OLS) }\end{array}$ & ne & I & I \\
\hline
\end{tabular}

Vir: Iastni izračuni

\section{Sklep}

$\checkmark$ prispevku so analizirani dejavniki, ki vplivajo na razlike $\vee$ velikosti javnega sektorja $\vee$ demokratičnih in razvitih državah, pri čemer analiza temelji na vzorcu 32 držav. Glavno vprašanje, na katero se poskuša odgovoriti, je, kateri ekonomski, družbeni, politični, demografski in kulturni dejavniki vplivajo na razlike $\vee$ velikosti javnega sektorja med državami, s ciljem dobiti teoretične in praktične osnove za razvoj sodobne ekonomske teorije oblasti. S tem v zvezi je pomemben prispevek analize tudi analiza dejavnikov makro obsega regulacije, saj je to ena izmed redkih analiz na tem področju. Splošna ugotovitev analize je, da očitni fiskalni in nefiskalni del javnega sektorja nastopata kot substituta, kar pomeni, da večji javni izdatki

\section{4 \\ Uprava, letnik II, 1/2004}




\section{Dejavniki razlik v velikosti fiskalnega in nefiskalnega dela javnega sektorja}

implicirajo manjši obseg regulacije in nasprotno, pri čemer naj bi bili naraščajoči javni izdatki povezani z ekonomskim napredkom družbe. Analiza je tudi pokazala na negativne učinke staranja prebivalstva in urbanizacije, ki povečujeta javne izdatke, poleg tega pa so prikazani tudi nekateri novi dejavniki, ki pomembno vplivajo na velikost javnega sektorja. $\vee$ zvezi s tem je bilo npr. ugotovljeno, da obstoj proporcionalnega volilnega sistema in politična decentralizacija povečujeta javne izdatke, kar je pomembna ugotovitev $\vee$ povezavi s procesi reforme političnih institucij in strukture oblasti, ki nikakor ne smeta pretirano povečevati javnih izdatkov in $\mathrm{s}$ tem posledično povečevati davčne obremenitve zasebnega sektorja. Po drugi strani je bilo v povezavi z velikostjo nefiskalnega dela javnega sektorja ugotovljeno, da npr. ekonomska razvitost, neenakost $v$ porazdelitvi dohodka in velikost države negativno vplivajo na makro obseg regulacije $\vee$ gospodarstvu, medtem ko državno lastništvo podjetij pozitivno vpliva na obseg regulacije. $V$ splošnem lahko trdimo, da so ekonomski dejavniki pomembnejši pri utemeljevanju razlik $\vee$ obsegu izdatkov za nakupe dobrin in storitev ter $v$ obsegu regulacije, medtem ko so politični, družbeni in kulturni dejavniki pomembnejši za utemeljevanje razlik $\vee$ obsegu transfernih izdatkov, pri čemer velja poudariti, da je nadaljnja analiza potrebna predvsem pri identifikaciji »mikro" dejavnikov velikosti javnega sektorja, s čimer bi se v večji meri odpravil tudi dvom $v$ obstoječo specifikacijo ekonomskega modeliranja na področju teorije oblasti.

\section{Literatura in viri}

- Alesina, A., Glaeser, E., Sacerdote, B. (2001): Why Doesn't the US Have a European-Style Welfare System?, NBER, Cambridge.

- Alesina, A., Wacziarg, R. (1998): Opnenness, Country Size and the Government, Journal of Public Economics, 69, str. 305-321.

- Alesina, A., Spolaore, E., Wacziarg, R. (2003): Trade, Growth and the Size of Countries, Harvard University, Cambridge.

- Annett, A. (2000): Social Fractionalization, Political Instability, and the Size of Government, IMF, Washington.

- Armey, D. (1995): The Freedom Revolution, Regnery Publishing, Washington.

- Bailey, S. J. (2002): Public Sector Economics, Palgrave, Basingstoke.

- Beck, T., idr. (2001): New tools and new tests in comparative political economy: the database of political institutions, World Bank Economic Review, 15, 1, str. 165-176.

- Brennan, G., Pincus, J. (1996): A minimalist model of federal grants and flypaper effects, Journal of Public Economics, 61, 2, str. 229-246.

- De Mello, L. (1999): Fiscal Federalism and Government Size in Transition Economies. IMF, Washington.

- $\quad \operatorname{EBRD}$ (2001): Annual Report, EBRD, London. 


\section{Primož Pevcin \\ Dejavniki razlik v velikosti fiskalnega in nefiskalnega dela javnega sektorja}

- Eichner, T., Wagener, A. (2002): Increases in risk and the welfare state. CESIFO, München.

- Elections around the world (2003), Electionworld.org.

- Encarta Encyclopedia (2003), Microsoft, Dublin.

- Gujarati, D. (2002): Basic Econometrics, McGraw-Hill, New York.

- Gwartney, J., Lawson, R. (2002): Economic Freedom of the World, Fraser Institute, Vancouver.

- Holsey, C., Borcherding, T. (1997): Why Does Government's Share of National Income Grow, v: Mueller, D. (ur.): Perspectives on Public Choice, CUP, New York, str. 569-590.

- Lane, J. (1995): The Public Sector, SAGE Publications, London.

- OECD (1997): Report on Regulatory Reform, OECD, Paris.

- OECD (2001): Economic Outlook, OECD, Paris.

- Persson, T. (2001). Do Political Institutions Shape Economic Policy?, NBER, Cambridge.

- Persson, T., Tabellini, G. (1999): Political Economics and Public Finance, NBER, Cambridge.

- Pevcin, P. (2003): Analiza obsega in strukture državnih izdatkov: politično-ekonomski vidik. X. Dnevi slovenske uprave, Zbornik posvetovanja, Fakulteta za upravo, str. 283-296.

- Pevcin, P. (2004): Determinants of the size of government and their implications for the reform of public sector in Slovenia, doktorska disertacija, Ekonomska fakulteta.

- Posner, R. (1971): Regulation as taxation, The Bell Journal, 2, 1, str. $22-50$.

- Pryor, F. (2002): Quantitative notes on the extent of governmental regulations in various OECD nations, International Journal of Industrial Organization, 20, 5, str. 693-714.

- Rodrik, D. (1998): Why do more open economies have bigger governments?, Journal of Political Economy, 106, 5, str. 997-1032.

- Ruggie, J. (1982): International Regimes, Transactions, and Change, International Organization, 36, 2, str. 379-415.

- Schiavo-Campo, S., idr. (1997): An International Statistical Survey of Government Employment and Wages. World Bank, Washington.

- Tanzi, V., Schuknecht, L. (2000): Public Spending in the 20th Century. CUP, Cambridge.

- U. S. Census (2001): International Database, Bureau of Census, Washington.

- Wolf, M. (2001): Will Technology and Global Capital Markets Change the Scope of Government?, Cato Journal, 21, 1, str. 143-150.

- World Development Indicators (2000, 2001, 2002), World Bank, Washington.

Primož Pevcin je leta 1999 diplomiral, leta 2002 magistriral in leta 2004 doktoriral na Ekonomski fakulteti v Ljubljani s področja ekonomije. Zaposlen je kot mladi raziskovalec na Fakulteti za upravo, $v$ svojem raziskovalnem delu se $v$ največji meri ukvarja z makroekonomskimi vprašanji in ekonomsko analizo politike. 


\section{SUMMARY}

\section{Factors Affecting Cross-Country Differences in the Size of Budgetary and Non-Budgetary Public Sector}

One of the major issues in social sciences is the expansion in the size of the public sector. In the majority of countries, especially in developed ones, the size of the public sector, measured with a share of expenditure in gross domestic product, grew rapidly in the last few decades. The growth in size of the public sector has been associated with high costs of service provision, waste of resources, large costs of compliance with regulation, adverse effects on incentives of intended beneficiaries, diversion of resources into rent-seeking activities and large deadweight costs in raising revenues. The question remains why taxpayers and voters have allowed such expansion of the public sector, one possible explanation being that voters probably do not recognise the link between taxation, incentives and economic efficiency. Besides, growth was not fully symmetrical in all countries, therefore initial differences caused large variations in the size of the budgetary public sector across countries. In addition, the size of the non-budgetary public sector also varies substantially across countries, although no uniquely adopted measure of its size exists.

Consequently, the main question that ought to be answered in the article is, why such differences exist in the size of the public sector across countries and which factors shape those differences. More theoretically and in connection to regulatory activities of the public sector, the question is what are the reasons behind the fact that one country is more laissez-faire than the other. Namely, fiscal instruments are only one of two instruments for executing public policy, since the other instrument is regulation. This so-called "quiet side" of public sector activity contributes importantly to the overall size of the public sector and is of absolute importance to recognise this "invisible foot". Therefore, it is vital to measure the size of both the "budgetary" and "non-budgetary" public sector, since not just the public expenditure ratio but also the extent of regulation ultimately differentiates big from small public sectors.

The existing literature on the differences in size of public sectors across countries and the factors behind it is not so comprehensive as the literature on growth of government. Still, more recent literature focuses more on the political economy determinants, such as size of country, trade openness and the degree of integration in the world economy, level of economic development, preferences and the heterogeneity of taxpayers, structure of government 
and political institutions, social fractionalisation etc. Consequently, various economic, social, political, demographic and cultural factors that could shape the differences in the size of government across countries have been identified and employed in the empirical analysis in order to obtain and empirically verify theoretical and practical macro foundations of modern economic theory of government. The empirical analysis of the determinants that cause the differences in the size of public sector across countries revealed that political, social and cultural variables are more important in explaining the cross-country differences. Besides, it can also be observed that composition of public spending matters, as economic factors are most important in explaining the variation in the size of consumption spending and in the size of non-budgetary public sector, whereas political, social and cultural factors are more important in explaining the variation in the size of transfer spending. Nevertheless, the results obtained obviously indicate that the size of the budgetary public sector and the size of the non-budgetary public sector develop in opposite directions. One possible explanation being that fiscal instruments should act as a direct substitute to the regulatory activities of the public sector, substitution possibly taking place through so-called "transmission mechanism of government activities". 